\title{
Vulnerabilidade sacioambiental de Curitiba: correlação com os eventos de alagamentos registrados entre 2005 e 2010 pela Defesa Civil Municipal
}

\section{Socio-environmental vulnerability of Curitiba: correlation with flooding events registered between 2005 and 2010 by Civil Defense of Municipal}

\author{
Camila Cunico* \\ Marciel Lohmann**
}

\section{Resumo:}

*Pesquisadora Doutora e

O objetivo desse artigo é identificar a vulnerabilidade socioambiental da cidade de Curitiba - PR e correlacioná-la com os eventos registrados de alagamentos (2005 a 2010) e com as condiçôes sociodemográficas do município. Adotou-se a abordagem sistêmica como referencial teórico-metodológico, bem como os procedimentos de Alves (2006 e 2007) e Alves e Torres (2006), cujos procedimentos permitem a identificação das áreas de risco ambiental, de risco social e de vulnerabilidade socioambiental. Os resultados mostraram que quanto menor o grau de vulnerabilidade socioambiental, melhores são as condiçôes socioeconômicas da população, menor a quantidade de registros de eventos críticos e menor a quantidade de área submetida a risco ambiental.

\begin{abstract}
:
The aim of this paper was to identify the socio-environmental vulnerability of Curitiba city - PR, and to relate it to the recorded events of flooding (2005 to 2010), as well as to the socio-demographic characteristics of the county. The systemic approach was adopted as a theoretical-methodological reference, as well as the procedures of Alves (2006 and 2007) and Alves and Torres (2006), whose procedures allow identifying the areas of environmental risk, of social risk and socio-environmental vulnerability. The results show that the lower the degree of socio-environmental vulnerability is, the better are the socioeconomic conditions of the population, the fewer are the records of critical events and the lower is the amount of area subjected to environmental risk.
\end{abstract} - Departamento de Geociências .

** Pesquisador Doutor e Professor da Universidade Estadual de Londrina - Departamento de Geociências.
Palavras-chave: risco ambiental, risco social, vulnerabilidade socioeconômica, alagamentos.

Keywords: environmental risk, social risk, socio-economic vulnerability, census sector, critical events 


\section{INTRODUÇÁO}

A Conviver com situaçóes de vulnerabilidade, perigo e risco é atualmente comum para a população. No entanto, há variaçóes em relação ao grau de exposição, à capacidade de reação e a agilidade para restabelecer o padráo de normalidade diante do evento crítico. Segundo Nunes (2009), a grande maioria das alteraçóes nos padróes de risco e desastre que afetam diretamente a população é originária de episódios atmosféricos extremos que agem como indutores do risco, os quais, associados a outras modificaçóes ambientais em curso, influenciam o advento de catástrofes, desarticulando o território e atingindo diferentemente os grupos sociais.

Neste sentido, a intensidade dos desastres está diretamente associada às características físico-naturais e socioeconômicas que auxiliam a definiçẫo do grau de risco e de vulnerabilidade das comunidades afetadas. Assim, pode-se afirmar que o mesmo evento, ocorrendo em recortes geográficos distintos, ocasiona danos diferenciados, ou seja, a mesma quantidade de chuva em municípios diferentes, em função da vulnerabilidade e do risco aos quais estâo submetidos, podem sofrer desiguais perdas humanas, ambientais e materiais.

No entanto, as consequências são maiores ou menores de acordo com o grau de exposiçáo de cada indivíduo ou grupo social. Nesse caso, o espraiamento de diferentes usos da terra quando associado à falta de planejamento urbano estratégico resultam em um aumento significativo de exposição às catástrofes.

Contudo, compreender e analisar a relação existente entre desastres naturais, uso e cobertura da terra, e condições sociodemográficas constituem possibilidades para captar e traduzir os fenômenos de sobreposição e interaçấo entre os problemas sociais e ambientais, auxiliando de maneira ímpar o planejamento e até mesmo a reorganização do espaço geográfico.

É fundamental pensar as cidades a partir destas consideraçôes, uma vez que conquistaram lugar de destaque e sem precedentes diante das contradiçốes que nelas se materializam, concentrando alteraçóes nas dinâmicas naturais e sociais. É indispensável fazer uma releitura destas dinâmicas em funçấo da realidade observada, que reproduz situaçóes e espaços adequados para o estabelecimento demográfico, ao mesmo tempo em que surgem espaços problemáticos e altamente desqualificados. De maneira bastante pragmática, as cidades apresentam diferentes riscos e vulnerabilidades que acabam influenciando diretamente a segregação da população considerando-se as características do espaço. As áreas segregadas são bastante peculiares e heterogêneas quando comparadas umas às outras. No entanto, apresentam fortes traços de similaridades internas, principalmente quando guiadas pela estrutura organizacional que reflete aumento da população, desigualdade social e deterioraçáo do meio ambiente.

É necessário criar condiçôes para minimizar ou pelo menos atenuar tais situaçóes. Conforme discutido por Jacobi (2004) há uma estreita relação entre os riscos e a questáo do uso e cobertura da terra, pois esta delineia os problemas ambientais de maior dificuldade de enfrentamento e, contraditoriamente, é onde mais se identificam competências de âmbito municipal. Tal temática subordinou-se aos interesses das classes de renda alta e média alta; assim, os loteamentos periféricos, classificados como territórios irregulares, não atendem aos parâmetros urbanísticos estabelecidos e ficam excluídos dos acessos aos serviços e investimentos públicos, e as melhorias são conseguidas por meio de obras pontuais e corretivas.

Assim, a população menos favorecida está submetida a condiçóes urbanísticas e sanitárias precárias, sujeita, dessa forma, a situaçôes de risco e de degradação ambiental e da qualidade de vida. Assim, concomitante a essa situação, existe a tendência de este mesmo grupo populacional ser o mais atingido e prejudicado pela incidência de eventos críticos, que, por sua vez, expóem a população a riscos à saúde e à própria vida.

A preocupaçáo com a temática ambiental urbana, enfocando as características físico-naturais da cidade de Curitiba (Figura 1), os diferentes graus de vulnerabilidades e a existência de eventos críticos compóem o eixo central de discussões deste artigo. $\mathrm{O}$ recorte geográfico mencionado é composto por uma diversificação dos elementos que compóem as paisagens e apresenta heterogeneidade em relação à estruturação social, ou seja, uma segmentação e diferenciação social, demográfica, econômica e ambiental que propiciam maior ou menor vulnerabilidade face às catástrofes naturais.

Nesta perspectiva, este artigo tem como objetivo identificar a vulnerabilidade socioambiental do município de Curitiba e correlacioná-la com os eventos de alagamentos registrados pela Defesa Civil Municipal e às condiçóes sociodemográficas.

Assim, compreender os eventos críticos mais comuns que assolam o município de Curitiba e, com base nisso, discutir a situação socioeconômica e demográfica da população inserida em cada um dos graus de diferentes vulnerabilidades existentes na cidade, é uma alternativa analítica que permite não apenas caracterizar os grupos submetidos à segregação socioespacial, mas também a capacidade de mobilização e de respostas de cada um destes face às catástrofes naturais. 


\section{Localização do município de Curitiba - PR}
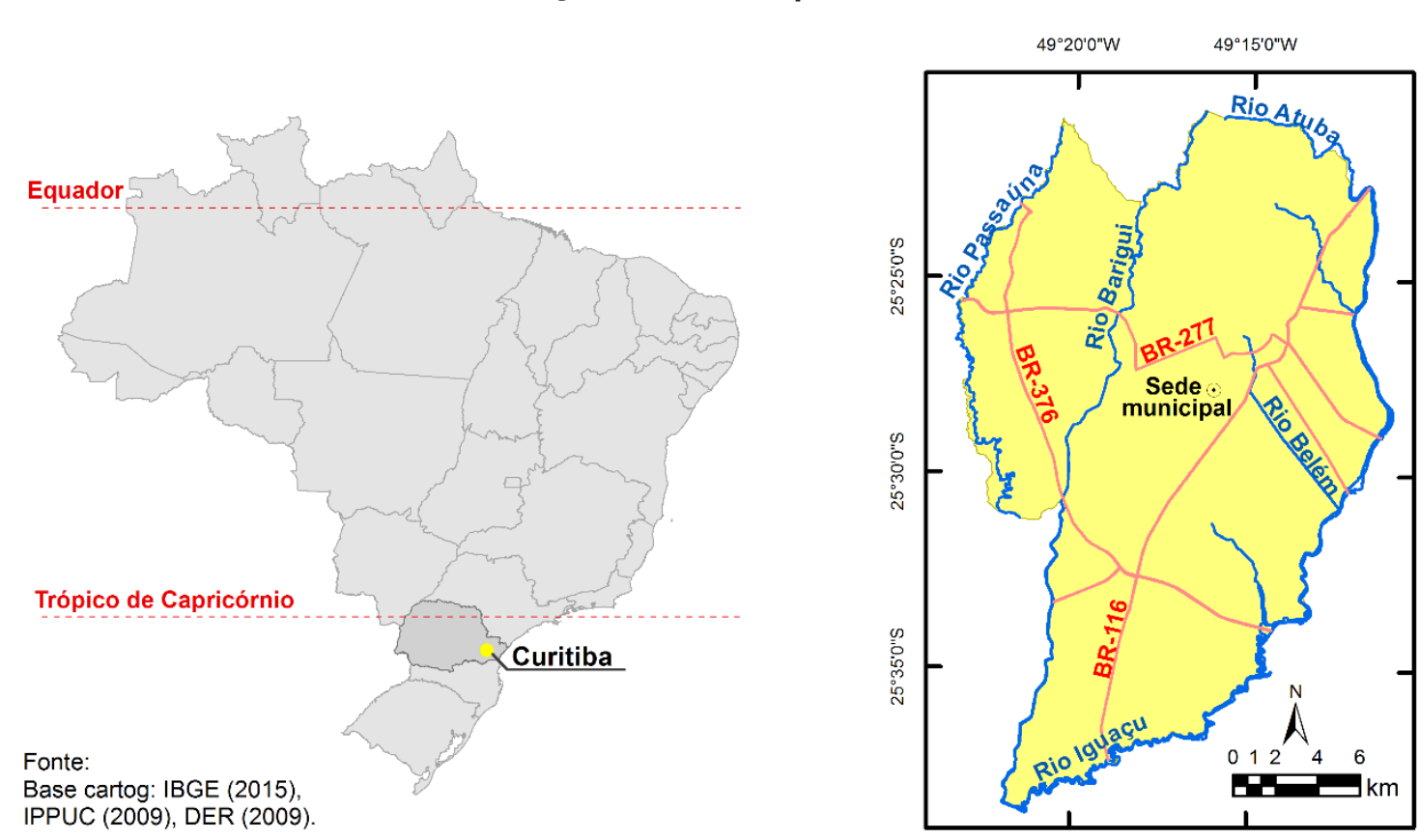

Figura 1 - Localização da área de estudo.

\section{FUNDAMENTAÇÁO TEÓRICO-METODO- LÓGICA}

As décadas de 1960 e 1970 previram o surgimento de muitos problemas ambientais em diferentes escalas de abrangência, remetendo para os centros das discussóes científicas e políticas a difusão de conceitos que estão associados à necessidade de garantir o bem estar individual e social sem, no entanto, comprometer a saúde ambiental. A dimensão humana diante de desequilíbrios ambientais torna-se objeto de estudo, formulando-se, assim, um corpo teórico e metodológico para reflexóes e análises práticas.

A difusão ampliada dos conceitos ambientais, na tentativa de superar a racionalidade científica com viés mecanicista e positivista, cuja consequência é a produção de um conhecimento fragmentado em disciplinas isoladas, busca articular as subáreas do conhecimento e suas respectivas modalidades teórico-metodológicas a uma perspectiva conjuntiva, baseada na interdependência dos fenômenos físicos, biológicos, culturais e sociais, e na possibilidade de (re)formular, auxiliar e intervir no planejamento ambiental e na gestáo territorial.

Tendo como base tal pensamento, uma das alternativas mais comuns, e já bastante difundidas no meio acadêmico, é a abordagem sistêmica, conhecida como Teoria Geral dos Sistemas (TGS), proposta introduzida pelo norte americano Defay em 1929, e que foi difun- dida principalmente a partir da década de 1970 pelos estudos de Sotchava (1978) e Bertalanffy (1973).

Considerada como fundamental para analisar os resultados deste artigo e para atingir o objetivo proposto, a concepçáo sistêmica é adotada como referencial metodológico, pois permite a convergência de diferentes fatores para uma análise baseada na totalidade, ou seja, na interdependência e dinâmica dos elementos físicos, biogeográficos, sociais e econômicos.

Apesar dos avanços teóricos obtidos das discussões e reflexôes sobre a questáo ambiental e seus conceitos específicos, ainda é muito incipiente a implantação efetiva de propostas que assegurem a justiça social, a eficiência econômica e o equilíbrio ambiental. Ressalte-se que esta tríade estimula cada vez mais a formação de redes multidimensionais, proporcionando a criação de uma visão mais sistêmica dos processos que integram a sociedade e a natureza.

A partir do referencial metodológico adotado, é importante a definição e breve discussão dos conceitos norteadores da pesquisa. Assim, a vulnerabilidade, interpretada sob o aspecto de eixo teórico, possibilita a compreensão analítica das condiçóes sociais a que a população está submetida, bem como das condições ambientais presentes no espaço geográfico. De acordo com Hogan e Marandola Jr. (2006), em todas as escalas, os riscos ambientais e a vulnerabilidade de ecossistemas, 
ou das pessoas em relação às dinâmicas e consequências ambientais, promovem a vulnerabilidade social. Assim, a vulnerabilidade ambiental do lugar, enquanto categoria de análise geográfica, pode ser compreendida a partir da relação existente entre os aspectos e condiçóes do meio ambiente e a vulnerabilidade social e demográfica da populaçáo que está neste contexto localizada.

Portanto, a identificaçáo da vulnerabilidade pressupôe não apenas a espacialização como sinônimo de localização geográfica, mas uma abordagem que proporcione a identificação da interação sociedade-natureza, ou seja, a perspectiva socioambiental.

Por integrar diferentes dimensôes, a vulnerabilidade passa a ser discutida sob o enfoque socioambiental, conceituada, segundo Cartier, et al. (2009) como uma coexistência ou sobreposição espacial entre grupos populacionais pobres, discriminados e com alta privação (vulnerabilidade social), que vivem ou circulam em áreas de risco ou de degradação ambiental (vulnerabilidade ambiental). Os mesmos autores afirmam que tal conceito está vinculado à exposição diferenciada frente aos riscos, e, indica a maior suscetibilidade de alguns grupos populacionais preverem, enfrentarem ou até mesmo sofrerem implicaçóes decorrentes de algum tipo particular de perigo (CUNICO; OKA-FIORI, 2014).

Alves (2006) afirma que o conceito de "vulnerabilidade" é capaz de traduzir os fenômenos de sobreposição espacial e interação entre os problemas sociais e ambientais. Diante de tal possibilidade adequa-se ao paradigma atual que contempla a dimensão socioambiental da pobreza. Essa reflexão é reforçada por Alves e Torres (2006), que afirmam que a "vulnerabilidade social" é analisada em relação a indivíduos, famílias ou grupos sociais e a "vulnerabilidade ambiental" é discutida em termos territoriais (regiōes e ecossistemas).

Além disso, é importante salientar que a vulnerabilidade pode ser compreendida a partir de uma visão prospectiva e definida como a probabilidade de sofrer uma perda no futuro relativa à qualidade de vida. Como se pode perceber, no conceito de "vulnerabilidade", a incerteza é um dos princípios que acaba sendo maximizado em funçáo das características da pessoa ou de um grupo social de responder ao risco, uma vez que se leva em consideração a condição social, o acesso a bens e a habilidade para a reação à situação de risco (ALWANG, et al., 2001).

Segundo os autores acima mencionados, a vulnerabilidade é uma resultante da situação de risco existente sendo, porém, subtraída a capacidade de enfrentamento ou de reação a esta situação. É necessário compreender o que os autores dissertam sobre "enfrentamento", que é definido por meio de três elementos básicos: a percepção (do próprio risco e das alternativas de açóes), a possibilidade de prevenção e mitigação do risco e, por fim, a açáo privada e pública, que deve se traduzir em investimentos. Dessa forma, há uma relação direta entre a vulnerabilidade, a exposição ao risco e o seu enfrentamento (reação).

A vulnerabilidade enquanto categoria de análise possui uma multiplicidade de sentidos e este artigo náo tem como objetivo finalizar essa construção conceitual. No entanto, adotou-se, para balizar as discussóes e análises dos resultados, que a vulnerabilidade deve ser compreendida em função do grau de suscetibilidade do recorte geográfico estudado diante da exposição ao perigo. Para isto, deve-se considerar a probabilidade e intensidade do perigo, da mesma forma que as características e condiçóes físico-naturais, sociais, econômicas e tecnológicas envolvidas no processo. Enquanto o risco é considerado como o resultado da relação existente entre a vulnerabilidade existente e a possibilidade de perigo, sendo, portanto, uma condição, ou seja, uma probabilidade de ocorrência de eventos no tempo e no espaço. É pertinente salientar que entende-se por perigo uma situação ou condição que tem potencial de acarretar consequências indesejáveis, é uma característica intrínseca (SÁNCHES, 2008).

\section{PROCEDIMENTOS TÉCNICOS E OPERA- CIONAIS}

Os procedimentos que permitem a sobreposição (ou coexistência espacial) dos elementos que compóem a vulnerabilidade socioambiental envolvem a utilização de métodos, técnicas e ferramentas de geotecnologias. Saliente-se que por meio da utilizaçáo de um sistema de informação geográfica e de métodos de geoprocessamento, os dados socioeconômicos e os demográficos, provenientes dos censos do IBGE, são integrados a dados ambientais, oriundos principalmente de bases temáticas do meio biofísico.

A manipulação de informações socioambientais demanda planejamento e decisóes sobre quais os dados cartográficos necessários para fundamentar a análise, a disponibilidade e a periodicidade desses dados, bem como o grau de detalhamento e de sua manipulação em diferentes softwares. De acordo com Santos (2004), todo o trabalho que visa auxiliar a definição de políticas públicas pressupóe o conhecimento sobre os componentes que formam o espaço, sendo necessário obter dados representativos da realidade, passíveis de interpretaçóes por diferentes configuraçôes. 
Para operacionalizar a identificação das condiçóes socioambientais do município de Curitiba, os procedimentos metodológicos adotados seguiram os pressupostos de Alves (2006 e 2007) e Alves e Torres (2006). A metodologia geral do trabalho consistiu na identificação das áreas de risco ambiental sobrepostas às malhas digitais dos setores censitários do município de Curitiba e na caracterização da população submetida a situaçóes diversas de vulnerabilidade socioambiental

De acordo com Alves $(2006,2007)$, as áreas de risco ambiental são identificadas como sendo aquelas próximas aos cursos de água e áreas com altas clinografias. Dessa forma, o autor adota como critério para defini-las:

Áreas localizadas muito próximas (50 metros) e/ ou às margens dos cursos d'água, pois apresentam risco de enchentes e/ou doenças de veiculação hídrica e outras associadas à contaminação da água;

Clinografia superior a $30 \%$, cuja geomorfologia predispóe à ocorrência de deslizamentos e processos erosivos mais intensificados.

No entanto, para o município de Curitiba, observa-se que o primeiro critério não pode ser adotado para a pesquisa sem que haja adaptaçôes, em função das características geomorfológicas da área de estudo. A utilizaçáo de "50 metros" para a criação de buffers com função de limite para a definição das áreas de possível ocorrência de enchentes acaba incluindo porções do território com clinografias acentuadas, principalmente acima de $8 \%$ e de 8 a $20 \%$ de declividade, cujas inclinaçôes do relevo não possibilitam tais eventos. Essas características ficam evidenciadas no entorno dos rios Barigüi, Belém e Ribeirão dos Padilhas.

Dessa forma, para a identificaçáo e o mapeamento das áreas de risco ambiental, utilizou-se a combinação das áreas identificadas como planícies fluviais, representadas pelas declividades inferiores a 3\% e geologicamente compostas por sedimentos areno-sílticos-argilosos inconsolidados, caracterizando tais espaços geográficos como de risco para a utilizaçáo antrópica, tendo em vista a possibilidade de eventos relacionados a alagamentos. É importante salientar que a escala adotada para o desenvolvimento da pesquisa foi de 1:10.000, sendo os layers que compóem a base sistemática e temática fornecidos pelo Instituto de Pesquisa e Planejamento Urbano de Curitiba, pela Coordenação da Região Metropolitana de Curitiba e pelo Instituto das Águas do Paraná. Saliente-se que tais layers permitiram a elaboraçáo de mapas temáticos que auxiliaram a caracterização da área e a análise dos resultados.

As áreas de risco mapeadas localizam-se de ma- neira descontínua no município de Curitiba. Portanto, para ser possível a combinação deste tema com as variáveis socioeconômicas (espacialização contínua) foi necessário compatibilizar as bases cartográficas. Dessa forma, categorizou-se cada um dos 75 bairros de acordo com a quantidade de área sob condição de risco ambiental (CUNICO, 2013), inserindo-os nas seguintes classes de risco ambiental: "muito baixo", "baixo", "médio", "alto" e "muito alto".

As áreas de risco social foram identificadas utilizando-se como recorte espacial os setores censitários do IBGE, que, para o município de Curitiba, totalizam 2.395 .

A partir das informaçóes obtidas pelo Censo de 2010, espacializaram-se, para cada um dos setores existentes no município, os indicadores sociodemográficos que representam o tamanho da população e a renda média dos residentes. A escolha desses indicadores justifica-se pela possibilidade de quantificar a população, bem como pela possibilidade de avaliar a privação social existente. De acordo com a proposta metodológica, os setores censitários com maior aglomeração de população e com baixa renda são aqueles com maior grau de risco social. Já os setores censitários que apresentam poucos habitantes e renda elevada são classificados como de menor grau de risco social.

Para facilitar a interpretação das variáveis analisadas foram gerados dois mapas: total de habitantes e total de rendimentos mensais, ambos por setor censitário. A partir da combinação desses dois temas e baseado na explicação supracitada, foi possível estabelecer o risco social, que foi categorizado como: "muito baixo", "baixo", "médio", "alto" e "muito alto". Essa agregação, apesar de generalizar as situaçóes de risco social, facilita a comparação entre os grupos, os bairros e simplifica a combinação das informações provenientes do risco ambiental.

Considerando-se a combinação dos mapas de risco ambiental e de risco social, elaborou-se o mapa de vulnerabilidade socioambiental (Figura 2). Assim sendo, a combinaçáo dos mapeamentos temáticos associada às análises empíricas, em particular às quantitativas e espaciais, elaborou-se a definiçáo das classes de vulnerabilidade socioambiental, categorizadas como: "muito baixa", "baixa", "média", "alta" e "muito alta".

De posse do mapa de vulnerabilidade socioambiental, correlacionaram-se os eventos registrados de alagamentos, deslizamentos e erosóes. Tais dados foram obtidos junto ao IPPUC (Instituto de Pesquisa e Planejamento Urbano de Curitiba), mas a fonte original é a Defesa Civil Municipal de Curitiba.

$\mathrm{O}$ método descrito permite a integraçáo dos 


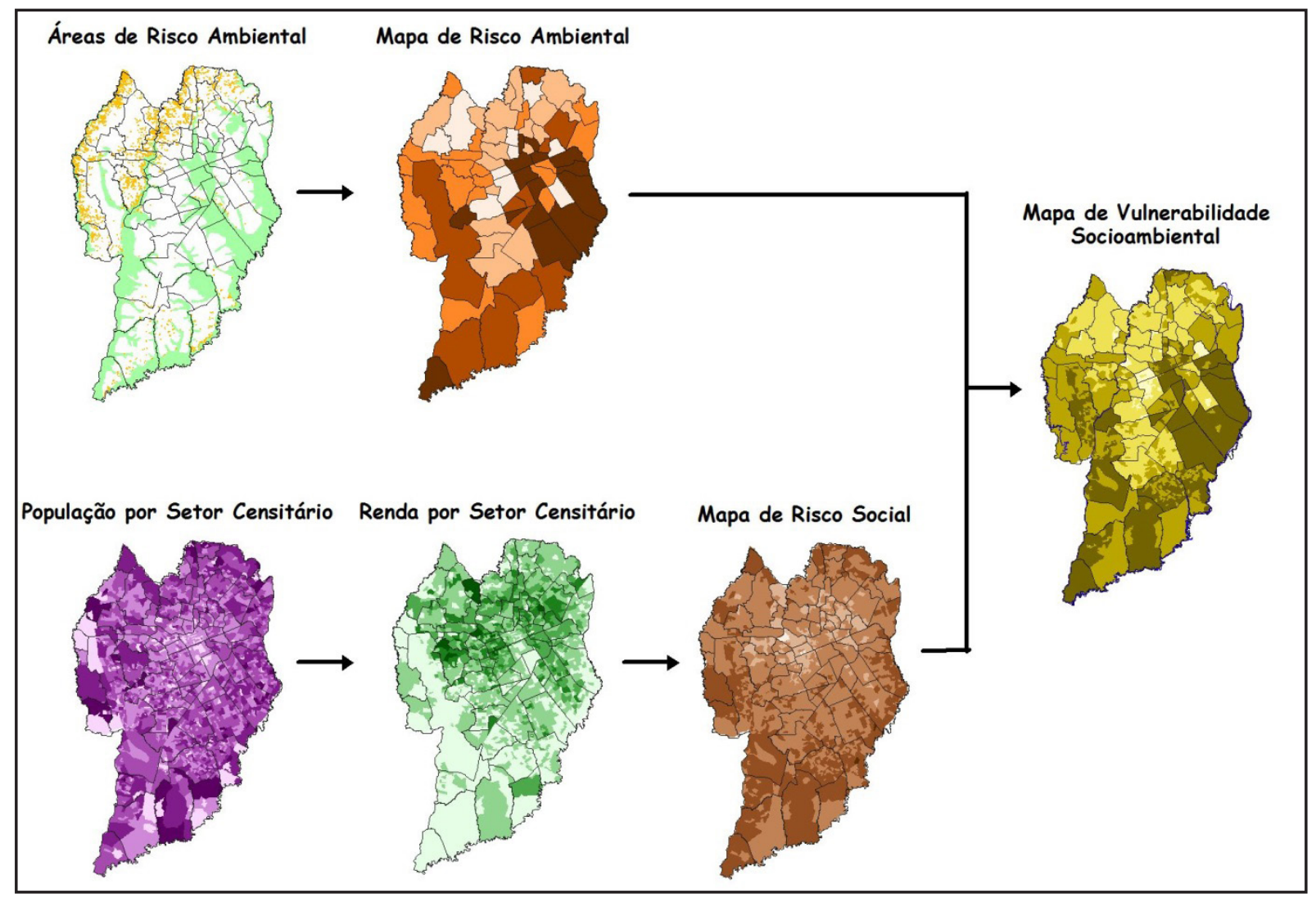

Figura 2 - Representação esquemática da metodologia utilizada para geração do mapa de vulnerabilidade socioambiental

dados ambientais e sociodemográficos, auxiliada pelas técnicas de geoprocessamento, operacionalizando-se os conceitos discutidos no referencial teórico.

\section{RESULTADOS}

\section{Bacias Hidrográficas de Curitiba}

O município de Curitiba está inserido na bacia hidrográfica do rio Iguaçu, que, por sua vez, compóe a bacia hidrográfica do rio Paraná. Para contextualizar, o rio Iguaçu possui uma extensão de $910 \mathrm{~km}$, drenando com seus afluentes uma área de $70.800 \mathrm{~km}^{2}$. Ao longo deste rio e de seus afluentes existem grandes áreas de várzeas naturais (wetlands), configurando a planície de inundação, as quais sofrem grandes pressóes ambientais em função da ampliação da expansão da ocupação urbana (YAMAMOTO, 2011). Destaque-se também que nas margens do rio Iguaçu existem atividades de extração de areia e argila.

De acordo com Yamamoto (2011), a qualidade das águas do rio Iguaçu é alterada por diferentes processos antropogênicos, fato que permite classificar o rio como o segundo mais poluído do Brasil, apenas atrás do rio Tietê em Sáo Paulo. É importante salientar que a concentração de poluição é mais significativa na porção do Alto Iguaçu, onde se localizam as nascentes. Dessa forma, 90\% dos poluentes correspondem à carga doméstica, enquanto que o resto é provocando por indústrias e resíduos direcionados pelas galerias de águas pluviais. É também na porção do Alto Iguaçu que está inserida a Região Metropolitana de Curitiba.

Especificamente no município de Curitiba, além da porção da bacia hidrográfica do rio Iguaçu, destacam-se outras cinco (Figura 3), todas no sentido norte-sul e tributárias da margem direita do rio anteriormente citado, cujas áreas podem ser verificadas na Tabela 1 .

Das cinco bacias hidrográficas apresentadas, saliente-se que somente a do rio Ribeirão dos Padilhas e do rio Belém nascem e deságuam no município de Curitiba. As demais possuem as nascentes localizadas nos municípios do entorno, e os exutórios são direto no rio Iguaçu, fora do contorno municipal de Curitiba, como é o caso do rio Passaúna, cujas nascentes estão no município de Almirante Tamandaré e a foz, em Araucária.

É comum a todas as bacias hidrográficas que compõem o sistema hídrico de Curitiba, a ocorrência de áreas com ocupaçóes irregulares, cujos assentamentos espontâneos e ocupaçáo dos loteamentos clandestinos datam, principalmente, das décadas de 1960 e 1970 (BOSCARDIN, 2008). 
Tabela 1 - Bacias hidrográficas e respectivas áreas no município de Curitiba -PR

\begin{tabular}{l|c|c}
\hline \multicolumn{1}{c|}{ Bacia Hidrográfica } & Área $\left(\mathrm{em} \mathrm{km}^{2}\right)$ & Porcentagem (\%) \\
\hline Ribeirão dos Padilhas & 32,09 & 7,37 \\
\hline Rio Passaúna & 38,92 & 8,94 \\
\hline Rio Atuba-Bacacheri & 63,74 & 14,65 \\
\hline Rio Barigüi & 66,36 & 15,25 \\
\hline Rio Belém & 89,67 & 20,61 \\
\hline Rio Iguaçu & 144,17 & 33,14 \\
\hline
\end{tabular}

Fonte: Mapa de bacias hidrográficas do município de Curitiba.

Org. Cunico, 2012.

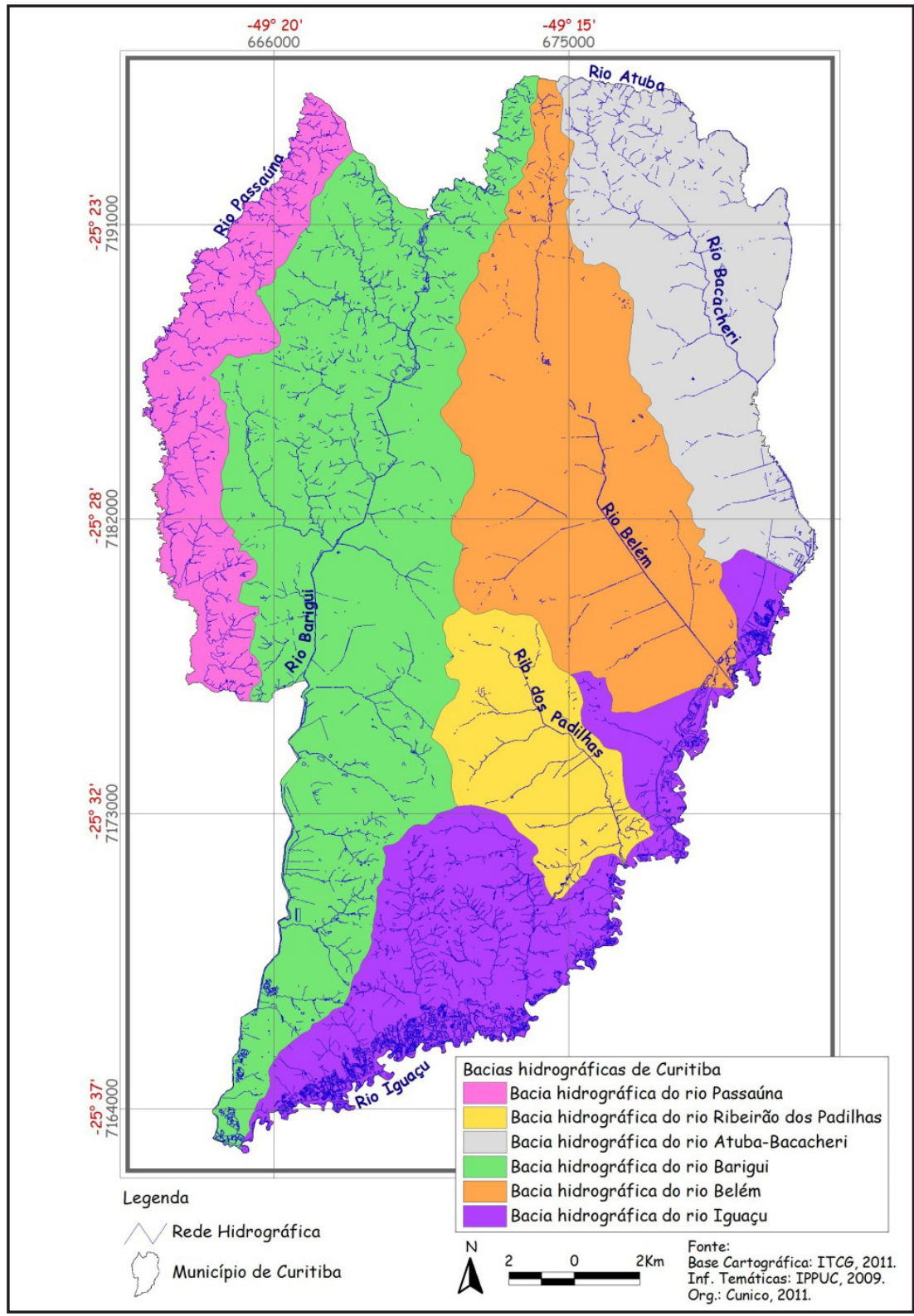

Figura 3 - Bacias hidrográficas do município de Curitiba - PR. 
Em relação à morfometria, os rios que drenam as bacias hidrográficas analisadas, apresentam distintas densidades e arranjos espaciais (destacam-se canais dendríticos e retangulares), justificados pelas características geológicas e geomorfológicas. Dessa forma, nas áreas cujo predomínio geológico é de rochas do Embasamento Cristalino (menos permeáveis), resulta maior densidade hídrica, ou seja, escoamento superficial mais acentuado e menor processo de infiltração das águas provenientes das chuvas.

Já na porção da Bacia Sedimentar, cujas propriedades físicas das rochas proporcionam maior permeabilidade, verifica-se menor densidade de rios, uma vez que há facilidade para a infiltração das águas das chuvas, bem como diminuição do processo de escoamento superficial.

\section{Risco Ambiental e Risco Social}

A partir da espacializaçáo dos eventos de alagamentos, deslizamentos e erosôes ocorridos em Curitiba no período de 2005 a 2010, que totalizaram 2.897, notou-se que $81,25 \%$ corresponderam aos eventos de alagamentos, que se tornaram problemas recorrentes na cidade e provocaram os maiores prejuízos materiais e até mesmo perda de vidas humanas, por afogamentos ou até mesmo por doenças infectocontagiosas de veiculação hídrica.

Segundo Botelho (2011), a ocorrência de cheias

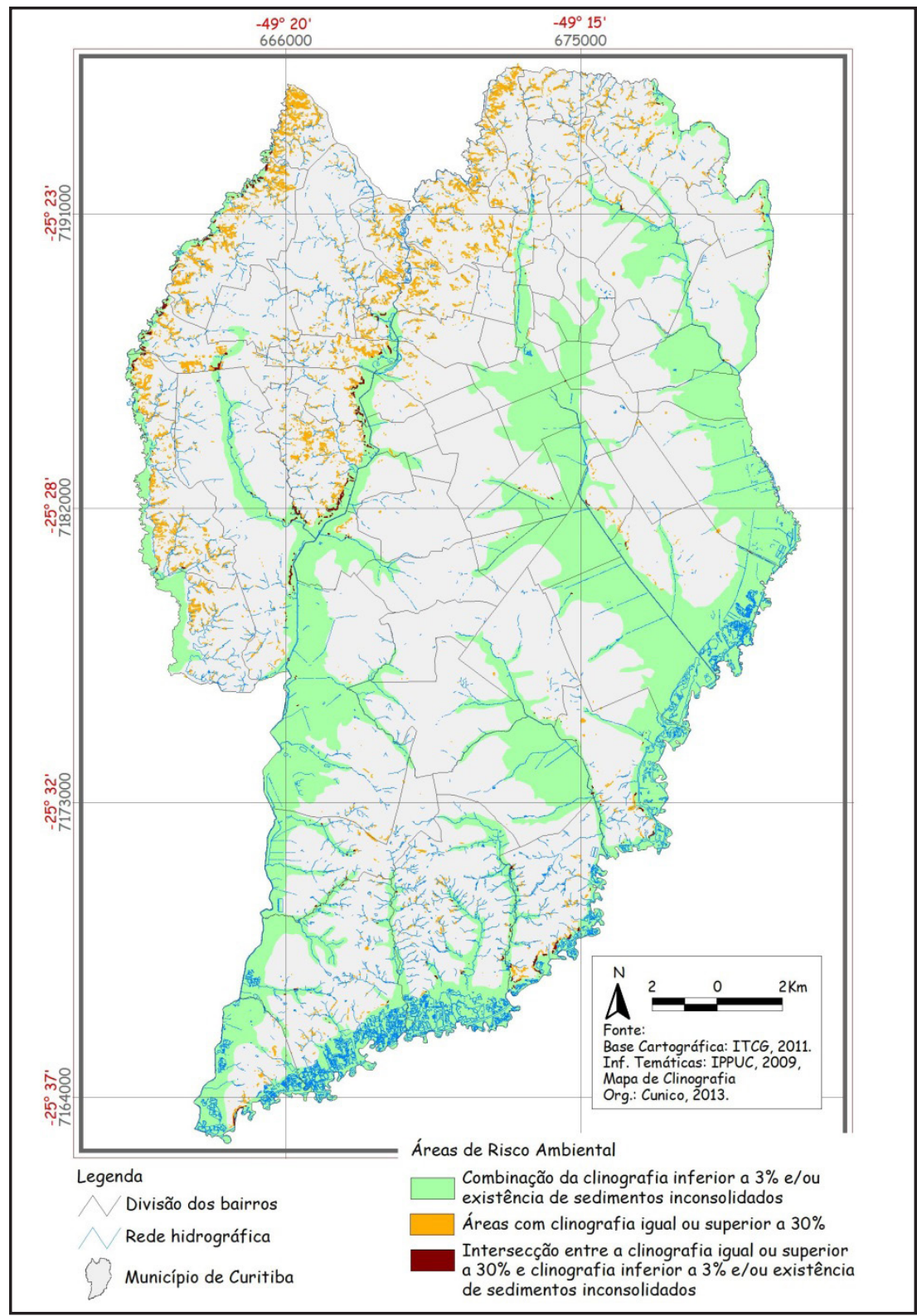

Figura 4 - Mapa de risco ambiental do município de Curitiba - PR 
ou transbordamento dos canais fluviais é um problema comum enfrentado pelas cidades brasileiras. Porém, tal fenômeno é de origem natural, característico das áreas de baixo curso dos rios e das áreas de planícies e terraços aluviais. Salienta ainda a autora que as cheias são controladas pelo volume e distribuição das águas das chuvas, pelo tipo e densidade da cobertura vegetal, pelas diferenças na cobertura pedológica, substrato geológico, características topográficas e geometria do canal fluvial. Porém, nas áreas urbanizadas, a frequência e a intensidade das cheias apresentam especificaçóes, uma vez que a ocupação intensa e desordenada, a impermeabilização de grandes áreas e a inadequação do sistema de drenagem urbana destacam-se em detrimento dos fatores naturais mencionados.

Já as erosôes e deslizamentos, apesar de os seus registros serem menos frequentes e estarem mais diluídos ao longo do período analisado, corresponderam a $18,75 \%$ do total. Vale destacar que tal diferença nas porcentagens correspondentes aos eventos pesquisados já era esperada, tendo em vista que o município de Curitiba apresenta pouca variação altimétrica, declividades acentuadas concentradas na porção norte e áreas antropizadas em todo o território.

As áreas caracterizadas pela recorrência dos eventos abordados são, na maioria dos casos, as únicas acessíveis às populaçóes de renda mais baixa, que, por sua vez, acabam construindo domicílios em condiçôes precárias, ampliando a condição de risco ambiental. Na Figura 4 visualiza-se o mapa de risco ambiental do recorte geográfico estudado.

Pode-se observar que as áreas definidas como de risco ambiental concentram-se em duas porçóes distintas do município de Curitiba: porção noroeste, evidenciada por apresentar as maiores diferenças topográficas (bacia hidrográfica do rio Passaúna); e porção centro/leste/sul, caracterizada pela existência de áreas com relevos planos (clinografia inferior a 3\%), bem como pela presença de materiais inconsolidados (bacias hidrográficas dos rios Bacacheri, Belém, Ribeirão dos Padilhas e Iguaçu). A bacia hidrográfica do rio Barigüi merece destaque, uma vez que sua extensão em relação ao município e também o seu eixo norte/sul contemplam tanto as áreas planas da porção sul quanto as rochas do embasamento cristalino da porção norte, responsáveis pelas maiores altitudes e pelas clinografias mais acentuadas.

Corroborando o que já foi evidenciado, as áreas sujeitas a inundações são as mais expressivas de Curitiba, correspondendo a $27,98 \%$ da área total do município. Já as que apresentam clinografia igual ou superior a $30 \%$, correspondem a $1,72 \%$ do total, enquanto que as áreas com sobreposição dos temas totalizam $0,11 \%$. Tais porcentagens mostram que $29,81 \%$ do território de Curitiba estão submetidos a condiçôes de risco ambiental.

Para exemplificar o uso e cobertura da terra nas áreas de risco ambiental identificadas, elaborou-se a Figura 5. A área representada pela Fotografia Aérea 1 corresponde ao bairro Lamenha Pequena, no qual predomina risco ambiental associado à clinografia igual ou superior a 30\%. O adensamento populacional é baixo, totalizando 1.056 habitantes de acordo com o Censo 2010.

A área representada pela Fotografia Aérea 2 corresponde ao bairro Abranches, cujas áreas de risco ambiental correspondem também à clinografia acentuada, porém com adensamento populacional mais significativo, totalizando, de acordo com o Censo 2010, 13.189 habitantes.

A área representada pela Fotografia Aérea 3 corresponde aos bairros Uberaba e Boqueirão. Ambos são caracterizados pela presença de áreas de risco ambiental associadas à clinografia igual ou inferior a 3\%.

Como é possível observar nesses locais, o adensamento populacional é mais intenso, sendo que a população correspondente aos dois bairros é de 145.234 habitantes, segundo o Censo de 2010. Saliente-se que o rio Belém faz o limite político entre os bairros mencionados.

Com o objetivo de auxiliar na interpretação das

Tabela 2 - Classes de risco ambiental e respectivos limites em porcentagem.

\begin{tabular}{|c|c|}
\hline Classes de risco ambiental & $\begin{array}{c}\text { Porcentagem limite da classe em relação ao total da área do } \\
\text { bairro sob condição de risco ambiental } \\
\text { Inferior a } 5 \%\end{array}$ \\
\hline Muito baixo & 5,1 a $15 \%$ \\
\hline Baixo & 15,1 a $30 \%$ \\
\hline Médio & 30,1 a $50 \%$ \\
\hline Alto & Superior a $50,1 \%$ \\
\hline Muito alto &
\end{tabular}

Org.: Cunico, 2016 

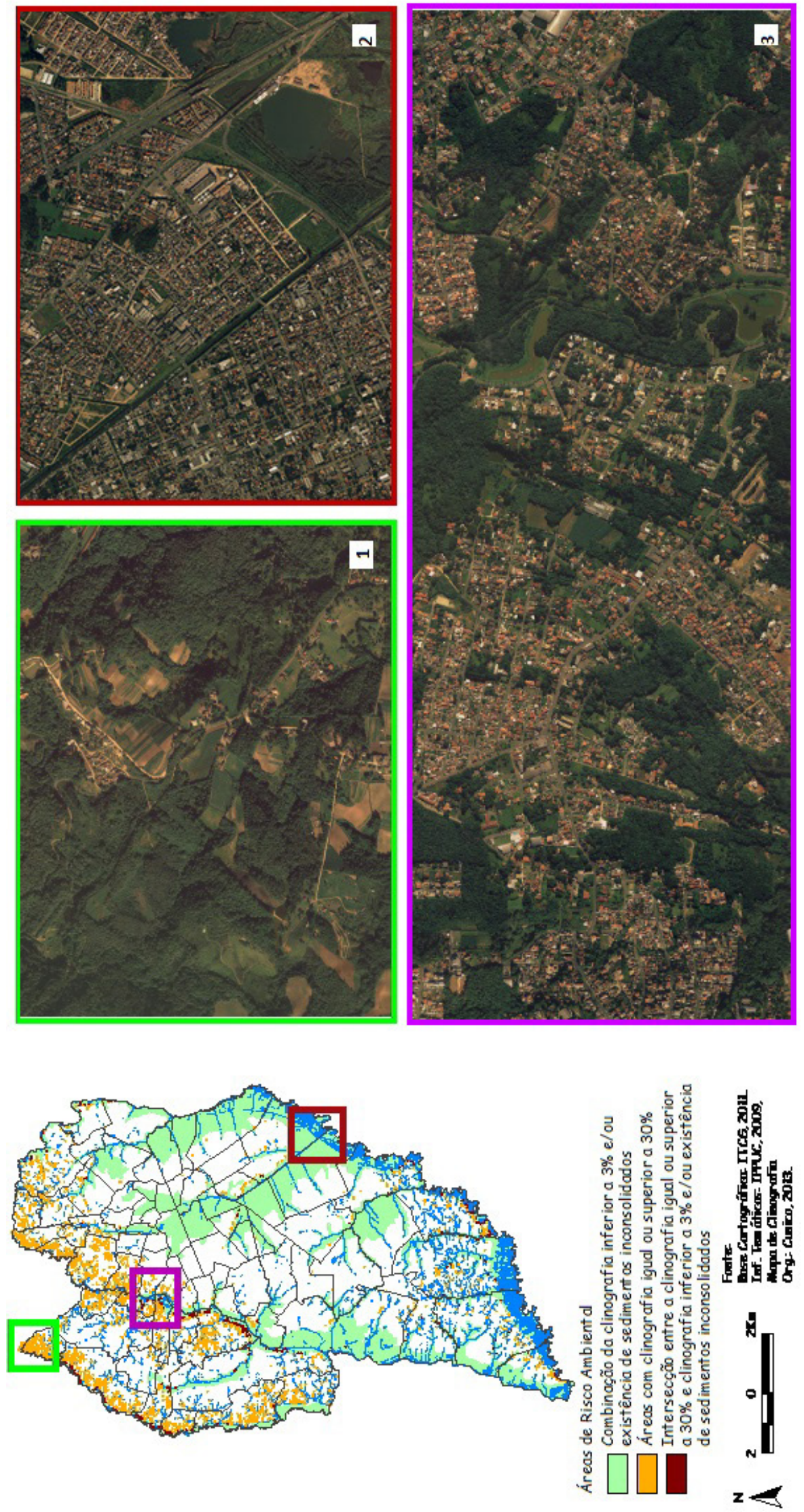

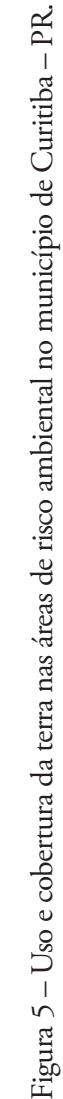

Geografia, Ensino \& Pesquisa, Vol. 21 (2017), n.3, p. 165-185

ISSN: 2236-4994 DOI: 10.5902/2236499424724 


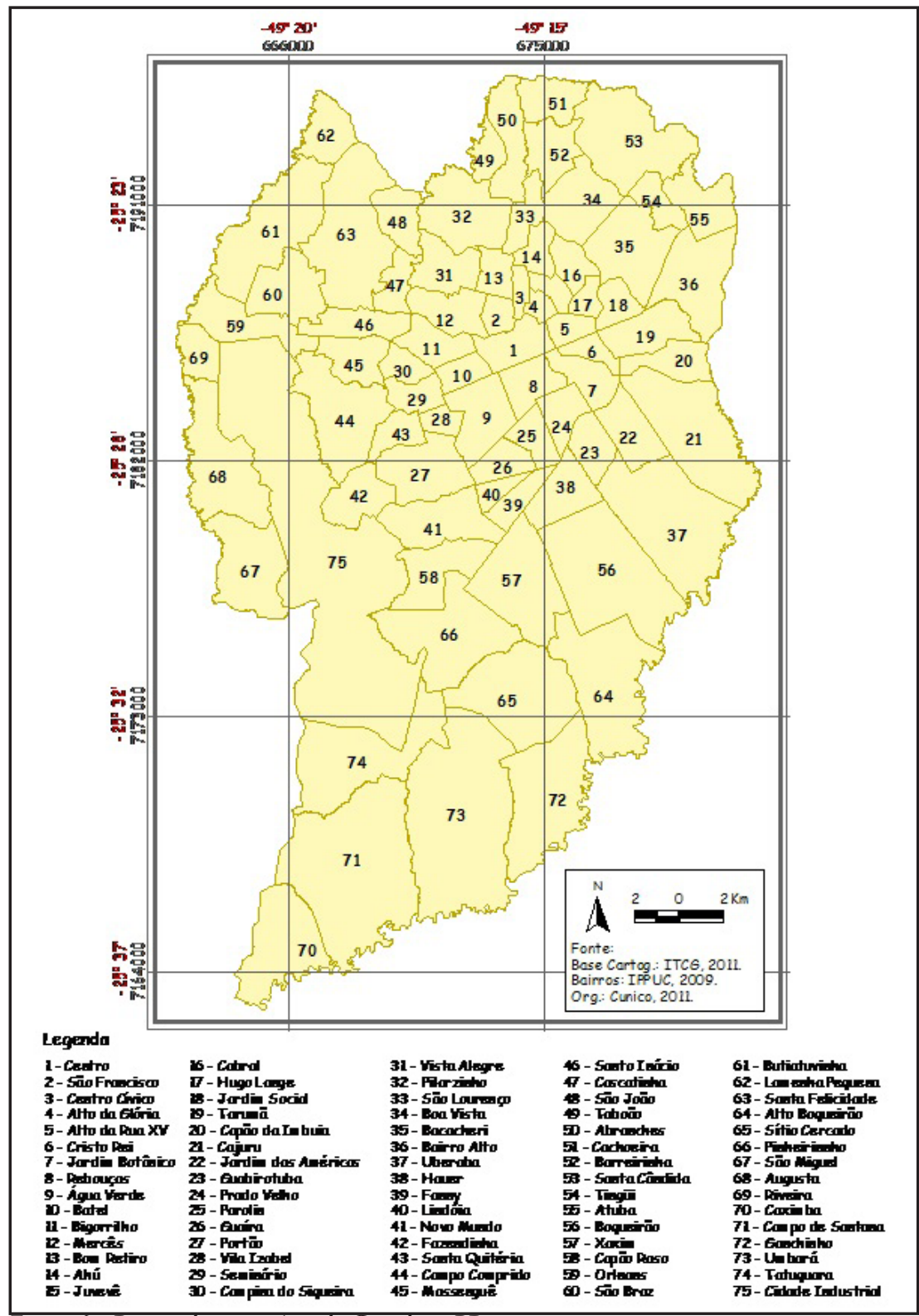

Figura 6-Bairros do município de Curitiba - PR.

temáticas abordados e também a localização espacial, elaborou-se a Figura 6 com os bairros de Curitiba.

De acordo com a metodologia utilizada nesse trabalho, faz-se necessário categorizar os bairros em função da variação de "muito baixo" a "muito alto" risco ambiental. A grande maioria dos trabalhos já existentes utiliza mapas e respectivas classes preestabelecidas pelas prefeituras municipais. No caso de Curitiba, optou-se por elaborar individualmente as classes de cada bairro, considerando sua área total e a quantidade desta área sob a condição de risco ambiental. Assim, elaborou-se a
Tabela 2 com as classes e limites desenvolvidos. A partir desses limites estabelecidos, foi necessário calcular a porcentagem de cada bairro sob a condição de risco ambiental e incluí-lo na respectiva classe, resultando na Figura 7.

Observando-a (Figura 7), nota-se que os bairros categorizados como de "muito baixo" e "baixo" risco ambiental estáo concentrados na porção centro/norte do município, totalizando 30 bairros, cujas características geomorfológicas estão associadas a clinografias médias e ausência de sedimentos inconsolidados. 


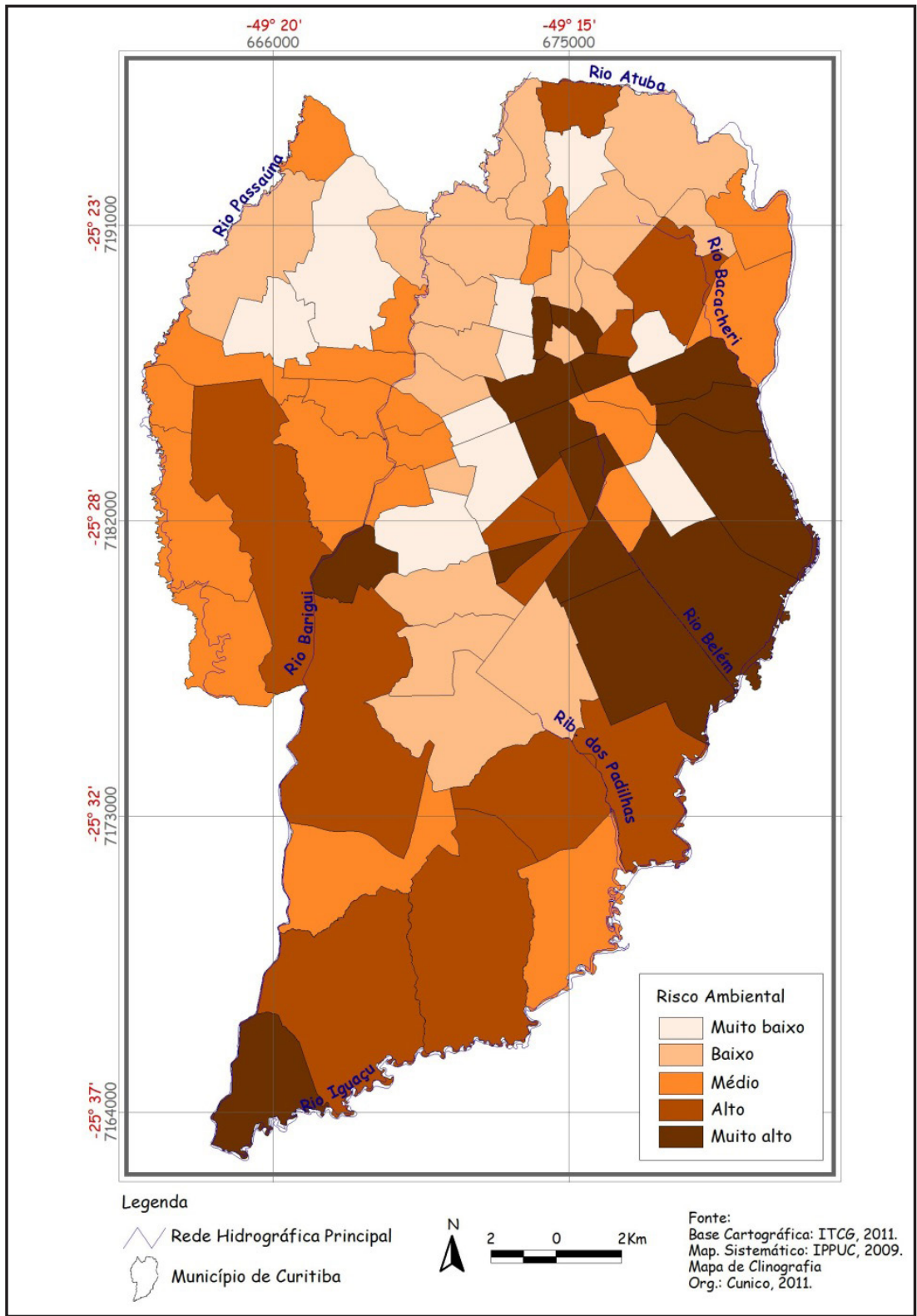

Figura 7 - Mapa de risco ambiental do município de Curitiba categorizado por bairro.

A classe de "médio" risco ambiental totaliza 20 bairros distribuídos geograficamente por todo o município, porém apresenta maior concentração na porção oeste, cujas áreas estão vinculadas à presença de clinografia superior a $30 \%$. Destacou-se o bairro Campo Comprido uma vez que apresentou risco ambiental e elevada concentração populacional com tendência de aumento, quando considerados os Censos Demográficos de 2000 e de 2010.

Os bairros categorizados como de "alto" risco ambiental, similarmente à classe anterior, estão distribuídos no município de Curitiba, totalizando 11 bair- ros, no entanto, a maior concentração está na porção sul, cujas áreas estão associadas à presença de planícies aluviais. Destacaram-se os bairros Campo de Santana, Cidade Industrial e Sítio Cercado, que, além de terem apresentado risco ambiental elevado, também manifestaram concentração populacional, sendo o último bairro mencionado o que possuí maior número de ocupações irregulares até o ano de 2005.

A concentração de bairros submetidos à condição de risco ambiental "muito alto" está agrupada na porção centro/leste do município de Curitiba, totalizando 15 bairros. É importante salientar que as áreas de risco 
ambiental estáo diretamente associadas à presença de planícies aluviais, com destaque para as dos rios Belém e Bacacheri. Dentre tais bairros sobressaíram-se o Cajuru, o Uberaba e o Boqueirão, uma vez que, além de estarem incluídos no raking dos 10 bairros mais populosos em 2010, também apresentaram o maior crescimento populacional absoluto entre os anos 2000 e 2010. Os bairros mencionados estão entre os cinco mais afetados quando considerados os eventos analisados, especialmente os alagamentos.

A partir da metodologia adotada para a elaboraçâo do mapa de risco ambiental de Curitiba, conclui-se que 46 bairros encontram-se em situação de risco ambiental médio, alto e muito alto.

Após a definição das áreas de risco ambiental, é necessário definir as áreas de risco social. Para tanto, utilizaram-se as variáveis sociodemográficas "tamanho da populaçãa" e "renda monetária", ambas coletadas a partir dos setores censitários do IBGE - Censo 2010 as quais se encontram espacializadas em CUNICO (2013).

A partir da combinação dos dois temas socioeconômicos supracitados, utilizando-se técnicas de geoprocessamento, elaborou-se o mapa de risco social por setores censitários (Figura 8), no qual optou-se por uma legenda cuja variação é de "muito baixo" a "muito alto", possível de verificar no Quadro 1.

No mapa de risco social, somente $0,17 \%$ do total da área do município de Curitiba encontra-se em situação de "muito baixo" risco social. Os setores censitários correspondentes a essa classe localizam-se nos bairros Batel e Bigorrilho e caracterizam-se por apresentar poucos habitantes e rendimento mensal mais elevado.

A classe de "baixo" risco social, que corresponde a 7,31\% de Curitiba, localiza-se na porção central, região cujos bairros apresentam as menores taxas de crescimento populacional absoluto e até mesmo decréscimo populacional, além de maior concentração de idosos. Acredita-se que tais características influenciam diretamente a classe de vulnerabilidade social, uma vez que em alguns setores censitários a população é menos concentrada, porém com renda mais elevada.

No município de Curitiba, predomina a classe de "médio" risco social, totalizando $247,72 \mathrm{~km} 2$ que correspondem a 56,95\%, distribuídos por todo município, porém concentrando-se mais na porção centro/norte. Caracteriza-se pela presença de setores censitários com máximo de 1.000 habitantes, cuja renda não ultrapassa R\$ 2.000,00 mensais. Já a classe de "alto" risco social, que corresponde a $35,46 \%$ do total de área do município de Curitiba, caracteriza-se por setores censitários com máximo de 1.500 habitantes, cuja renda não ultrapassa R \$ 1.300,00 mensais. Tal classe localiza-se em porçóes dos bairros do extremo norte de Curitiba. Os bairros mencionados na classe acima descrita, sobretudo os localizados ao sul de Curitiba, possuem características comuns: grandes contingentes populacionais, grande concentração de crianças e renda mensal baixa. Essas características acentuam a condiçấo de risco social.

A classe de "muito alto" risco social corresponde a menos de $1 \%$ do total de área de Curitiba, estando presente somente em dois bairros: Alto Boqueirão e Boqueirão. Os setores censitários inseridos nessa classe apresentam densidade demográfica bastante elevada e renda inferior a $\mathrm{R} \$ 650,00$ mensais.

A partir da metodologia adotada para a elaboração do mapa de risco social, conclui-se que $92,49 \% \mathrm{da}$ área total do município encontra-se em situação de risco social médio, alto e muito alto, fato que revela setores censitários com densidade populacional elevada e renda mensal baixa, que podem comprometer o processo de resiliência da população, de respostas adequadas do poder público aos momentos de crises e a maximização do risco socioambiental.

Eventos de alagamentos registrados entre 2005 e 2010 pela Defesa Civil Municipal de Curitiba - PR

O município é contemplado por eventos críticos, permitindo questionar se a infraestrutura urbana é capaz de minimizar os efeitos negativos que atingem, sobre-

Quadro 1 - Proposta de combinaçáo do total de habitantes e rendimento mensal em reais, por setor censitário, no município de Curitiba - PR.

\begin{tabular}{|l|c|c|}
\hline Classes do total de habitantes & Classes do rendimento mensal & Classes do risco social \\
\hline Superior a 1.501 & Inferior a $\mathrm{R} \$ 650,00$ & Muito alto \\
\hline $1.001-1.500$ & $\mathrm{R} \$ 651,00$ a $\mathrm{R} \$ 1.300,00$ & Alto \\
\hline $701-1.000$ & $\mathrm{R} \$ 1.301,00$ a $\mathrm{R} \$ 2.000,00$ & Médio \\
\hline $401-700$ & $\mathrm{R} \$ 2.001,00$ a $\mathrm{R} \$ 3.500,00$ & Baixo \\
\hline Inferior a 400 & Superior a $\mathrm{R} \$ 3.501,00$ & Muito baixo \\
\hline Org.: Cunico, 2012. & \multicolumn{2}{|}{} \\
\hline
\end{tabular}




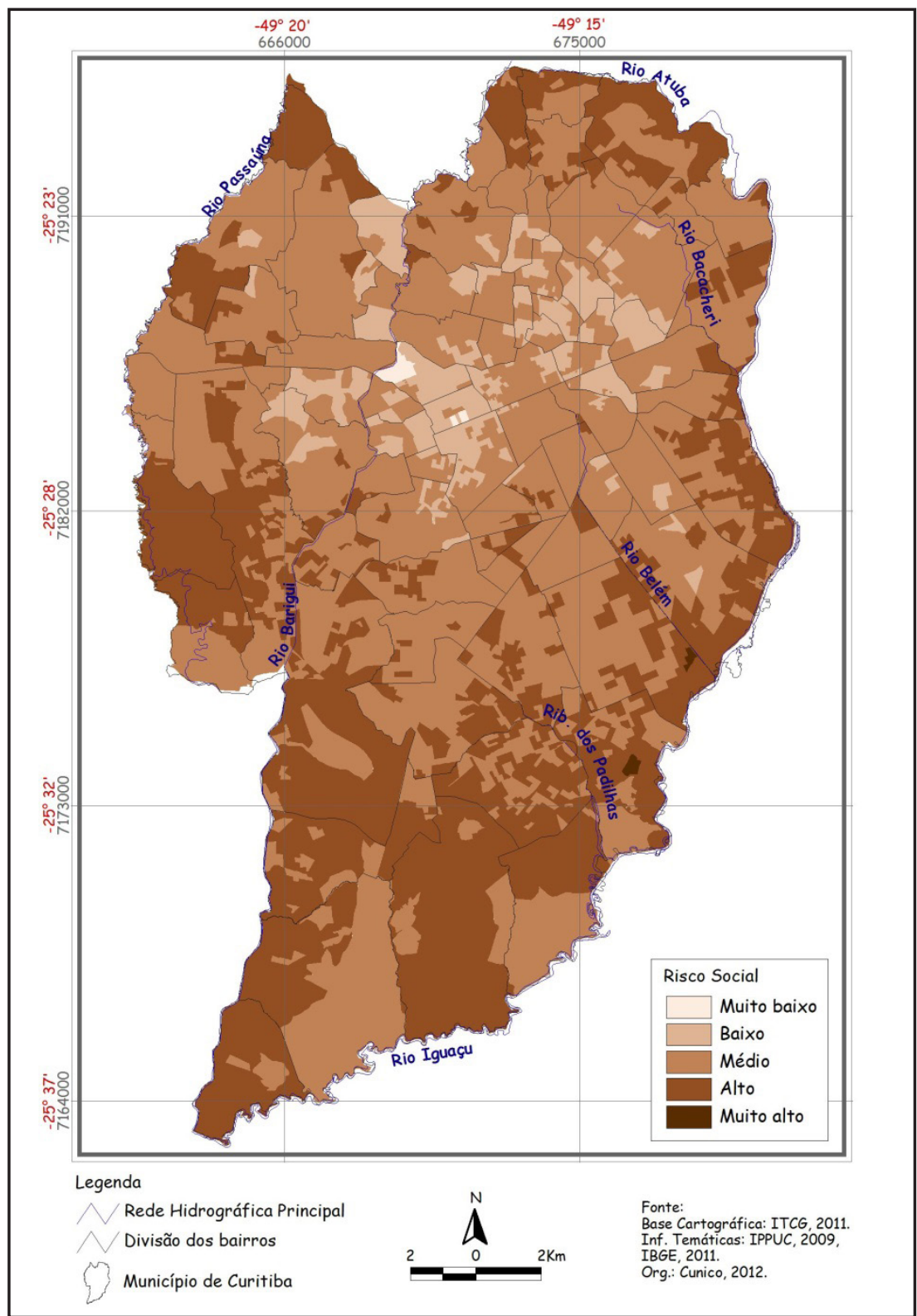

Figura 8 - Risco social no município de Curitiba - PR.

tudo, a população mais carente e a sua capacidade de mobilização e resposta. Os eventos extremos de origens distintas, que foram notificados pela Coordenadoria Municipal da Defesa Civil de Curitiba, e que atingiram a cidade no período de janeiro de 2005 a dezembro de 2010, podem ser visualizados na Tabela 3 .

$\mathrm{Na}$ Tabela 3, podemos verificar que grande parte das ocorrências registradas e cadastradas pela Coordenadoria Municipal da Defesa Civil de Curitiba são de origem hidrometeorológicas ou consequências de eventos dessa origem, e tal constatação e respectiva porcentagem ficam mais evidentes nas Figuras 9 e 10.

Em relação aos eventos de alagamentos (Figura
11), a bacia hidrográfica do rio Barigüi é a que apresenta maior quantidade de eventos registrados, correspondendo a $33,94 \%$, consequentemente os bairros inseridos nesse recorte geográfico são os mais acometidos. A bacia hidrográfica do rio Belém corresponde a $27,14 \%$; a do rio Atuba-Bacacheri a 20,05\%; a do rio Ribeirão dos Padilhas a $10,70 \%$; a do rio Iguaçu a $7,13 \%$; e a do rio Passaúna a 1,01\%. Ddestaca-se que a bacia hidrográfica do rio Barigüi é a maior de Curitiba, atravessando o município, de Norte a Sul, enquanto a bacia hidrográfica do rio Passaúna é a menor em termos de área.

Acredita-se que, para o período espacializado 
Tabela 3 - Eventos registrados no período de janeiro de 2005 a dezembro de 2010 para a cidade de Curitiba - PR

\begin{tabular}{|c|c|c|c|c|c|c|c|}
\hline \multirow{2}{*}{ Eventos } & \multicolumn{7}{|c|}{ Ano } \\
\hline & 2005 & 2006 & 2007 & 2008 & 2009 & 2010 & Total \\
\hline Alagamentos & 274 & 522 & 518 & 251 & 492 & 297 & 2.354 \\
\hline Deslizamentos & 1 & 1 & 1 & * & 14 & 12 & 29 \\
\hline Erosões & 21 & 35 & 197 & 149 & 69 & 43 & 514 \\
\hline $\begin{array}{c}\text { Desmoronamentos e } \\
\text { desabamentos }\end{array}$ & 4 & 11 & 33 & 32 & 52 & 44 & 176 \\
\hline Destelhamentos & 3 & 32 & 47 & 23 & 25 & 52 & 182 \\
\hline Queda de árvore ou galhos & 97 & 247 & 218 & 63 & 109 & 79 & 813 \\
\hline Queda de fios de energia & * & 4 & * & * & 4 & 6 & 14 \\
\hline $\begin{array}{l}\text { Risco de desabamento e } \\
\text { desmoronamento }\end{array}$ & 7 & 27 & 56 & 40 & 59 & 62 & 251 \\
\hline $\begin{array}{c}\text { Risco de queda de árvores ou } \\
\text { galhos }\end{array}$ & 2 & 4 & * & 6 & 9 & 9 & 30 \\
\hline $\begin{array}{c}\text { Total de registros acima especifi- } \\
\text { cados realizados pela Coordena- } \\
\text { doria Municipal da Defesa Civil de } \\
\text { Curitiba }\end{array}$ & 409 & 884 & 1.070 & 564 & 833 & 604 & 4.364 \\
\hline $\begin{array}{c}\text { Total de registros realizados pela } \\
\text { Coordenadoria Municipal da Defe- } \\
\text { sa Civil de Curitiba }\end{array}$ & 493 & 964 & 1.347 & 719 & 1.033 & 777 & 5.333 \\
\hline
\end{tabular}

Fonte: Coordenadoria Municipal da Defesa Civil de Curitiba, 2011.

Org.: Cunico, 2011.

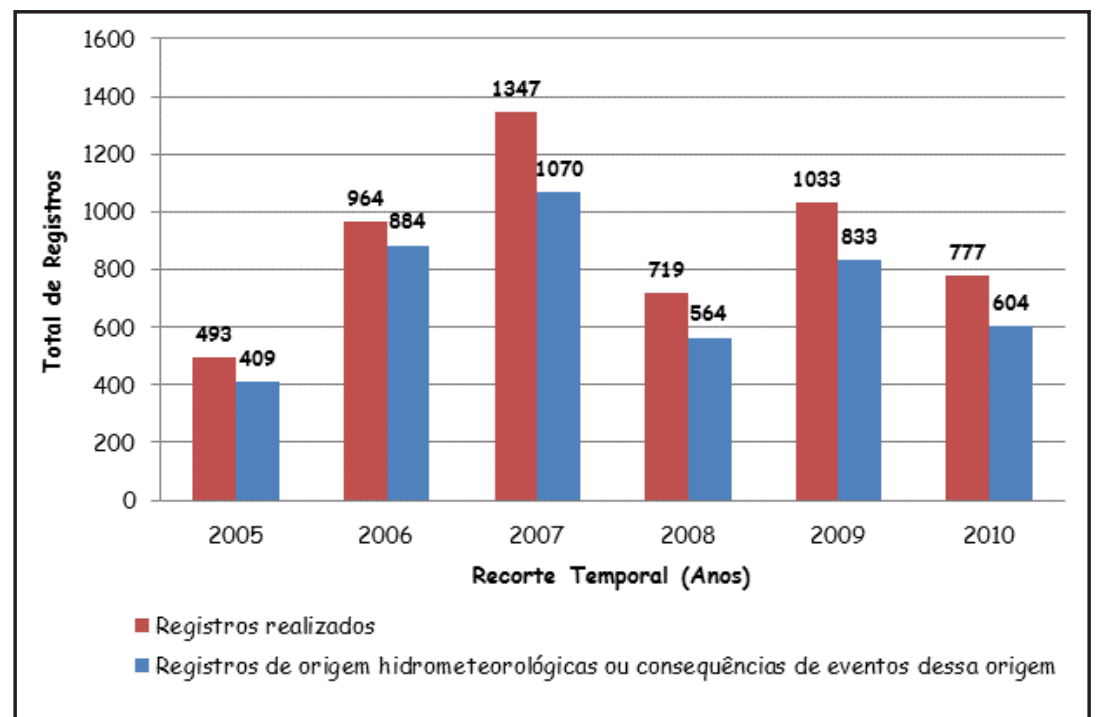

Figura 9 - Registros efetuados no período de 2005 a 2010 em Curitiba - PR. Fonte: Coordenadoria Municipal da Defesa Civil de Curitiba, 2011. 


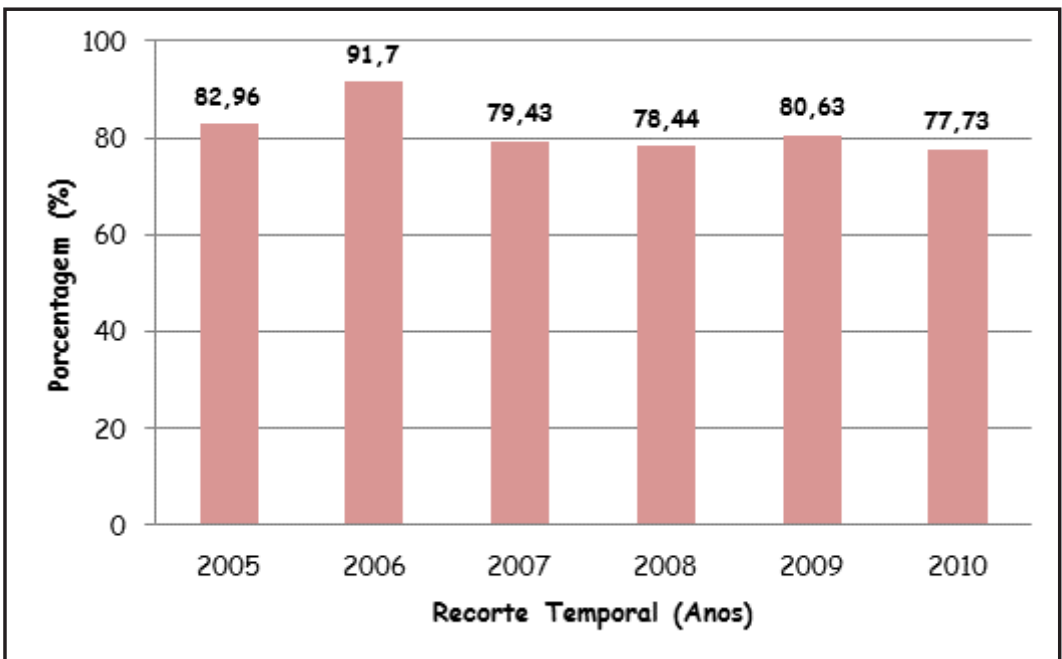

Figura 10 - Porcentagem de eventos de origem hidrometeorológicas ou consequências de eventos dessa origem em relação ao total registrado.

Fonte: Coordenadoria Municipal da Defesa Civil de Curitiba, 2011.

(2005 a 2010), a quantidade de eventos significativos estava diretamente relacionada à densidade populacional e à área impermeabilizada que cada uma das bacias hidrográficas possuía, intensificando ainda mais o problema. Deve-se salientar também que, associados a tais fatores, as precipitaçóes concentradas foram as principais causas que contribuíram para a ocorrência de alagamentos. Na Tabela 4 verifica-se a porcentagem de dias com ocorrência de alagamentos nas bacias hidrográficas que compóem o município.

No estudo de Lohmann (2011), não foram identificados os dias com e sem ocorrência de alagamentos para a bacia hidrográfica do rio Passaúna, tendo em vista o baixo número de registros. Conforme o mesmo autor, em todas as bacias hidrográficas a porcentagem de dias sem registros de alagamentos fica, em média, acima de 95\%. Porém, "nos 5\% restantes há registros de alaga- mentos, ou seja, de forma geral, em torno de 18 dias no ano têm-se registros de alagamentos" (p. 146).

Observando-se a Tabela 4, a bacia hidrográfica do rio Barigüi apresenta uma incidência baixa em relação à porcentagem de dias com ocorrência de alagamentos, no entanto, é a que mais apresentou registros no período de 2005 a 2010. Lohmann (2011) afirma que em função das características socioambientais das bacias, o tempo de resposta à precipitaçáo torna-se a variável principal para explicar tal dinâmica, ou seja, pelo fato de a bacia do rio Barigüi apresentar maior área, infere-se que o tempo de resposta entre a precipitaçáo e seu efeito seja mais longo, possibilitando um maior equilíbrio para os eventos pluviométricos de maior intensidade. Daí a menor percentagem de dias com ocorrência de alagamentos.

Tabela 4 - Porcentagem de dias sem e com ocorrências de alagamentos no período de 2005 a 2010

\begin{tabular}{|l|c|c|}
\hline Bacia hidrográfica & Dias com ocorrência em \% & Dias sem ocorrência em \% \\
\hline Rio Belém & $7,6 \%$ & $92,4 \%$ \\
\hline Rio Atuba-Bacacheri & $5,4 \%$ & $94,6 \%$ \\
\hline Rio Ribeirão dos Padilhas & $4,7 \%$ & $95,3 \%$ \\
\hline Rio Barigüi & $4,1 \%$ & $95,9 \%$ \\
\hline Rio Iguaçu & $2,8 \%$ & $97,2 \%$ \\
\hline
\end{tabular}

Fonte: Lohmann, 2011 

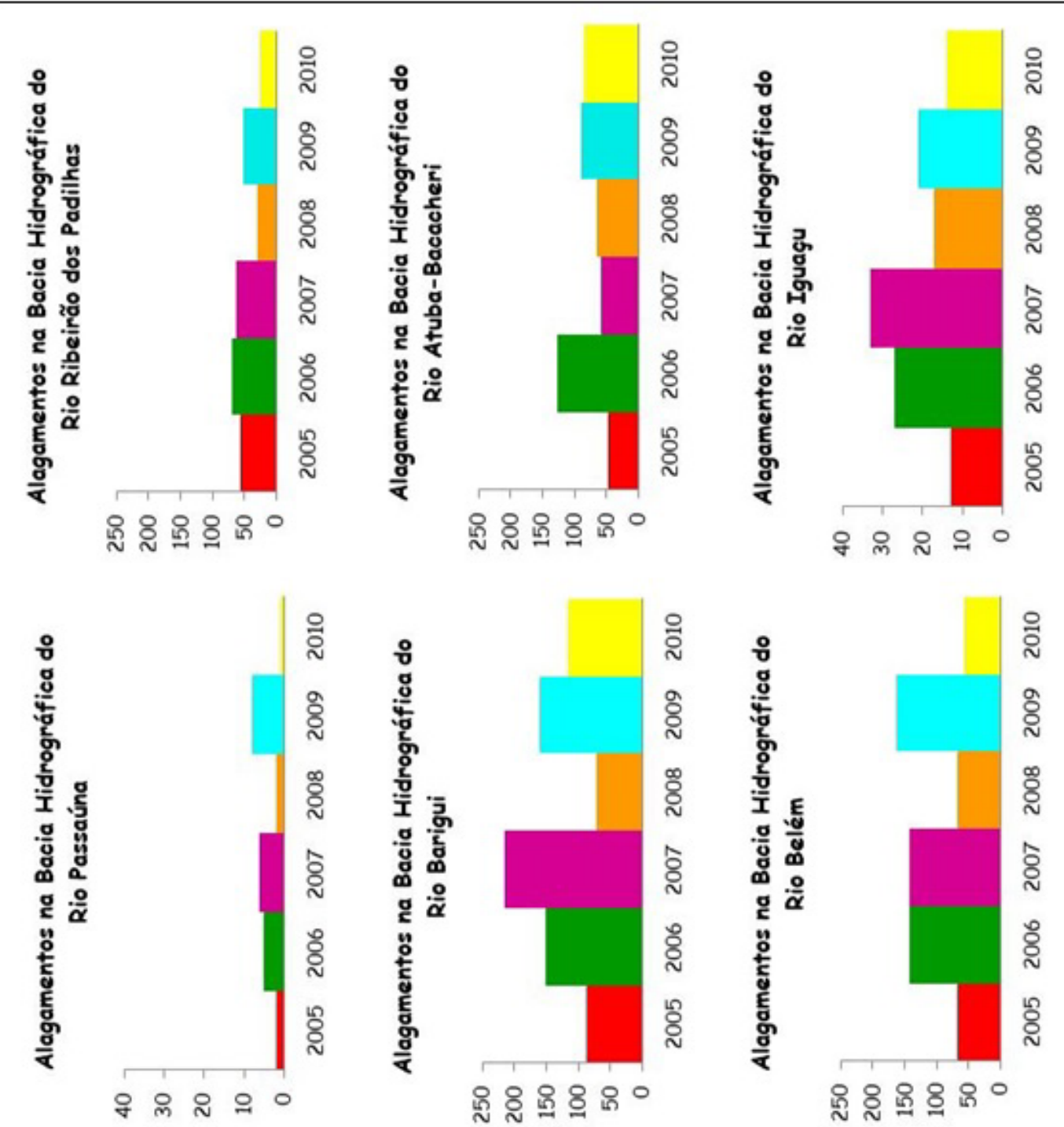

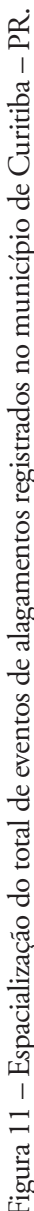

Geografia, Ensino \& Pesquisa, Vol. 21 (2017), n.3, p. 165-185

ISSN: 2236-4994 DOI: 10.5902/2236499424724 
Em relação aos bairros, durante o período de 2005 a 2010, os mais acometidos por eventos de alagamentos foram: Cidade Industrial (272 registros), Cajuru (158), Uberaba (155), Sítio Cercado (137), Boqueirão (119), Xaxim (88), Bairro Alto (84), Novo Mundo (73), Tatuquara (71) e Pinheirinho (71). Tais bairros são os mais populosos de acordo com o Censo de 2010, com exceção do Bairro Alto e do Novo Mundo. Assim, também apresentaram os maiores índices de vítimas. A localização geográfica dos bairros mencionados corresponde às áreas topograficamente mais planas, que favorecem o pouco escoamento das águas pluviais e a ocorrência de eventos desse gênero.

\section{Vulnerabilidade Socioambiental}

A partir da combinação dos mapas síntese de risco ambiental e social foi elaborado o mapa de vulnerabilidade socioambiental (Figura 12).

A classe "muito baixa" vulnerabilidade socioambiental totaliza $8,38 \mathrm{~km}^{2}$ do município de Curitiba, o que representa $1,92 \%$ do total da área de estudo. Em relação a sua localização espacial, encontra-se mais concentrada na porçáo central da cidade, porém, nenhum bairro possui todo o seu limite inserido na referida classe. Portanto, porçóes dos bairros Água Verde, Batel, Bigorrilho, Bom Retiro, Jardim das Américas, Jardim Social, Portão, Santa Felicidade, São Braz e São Fran-

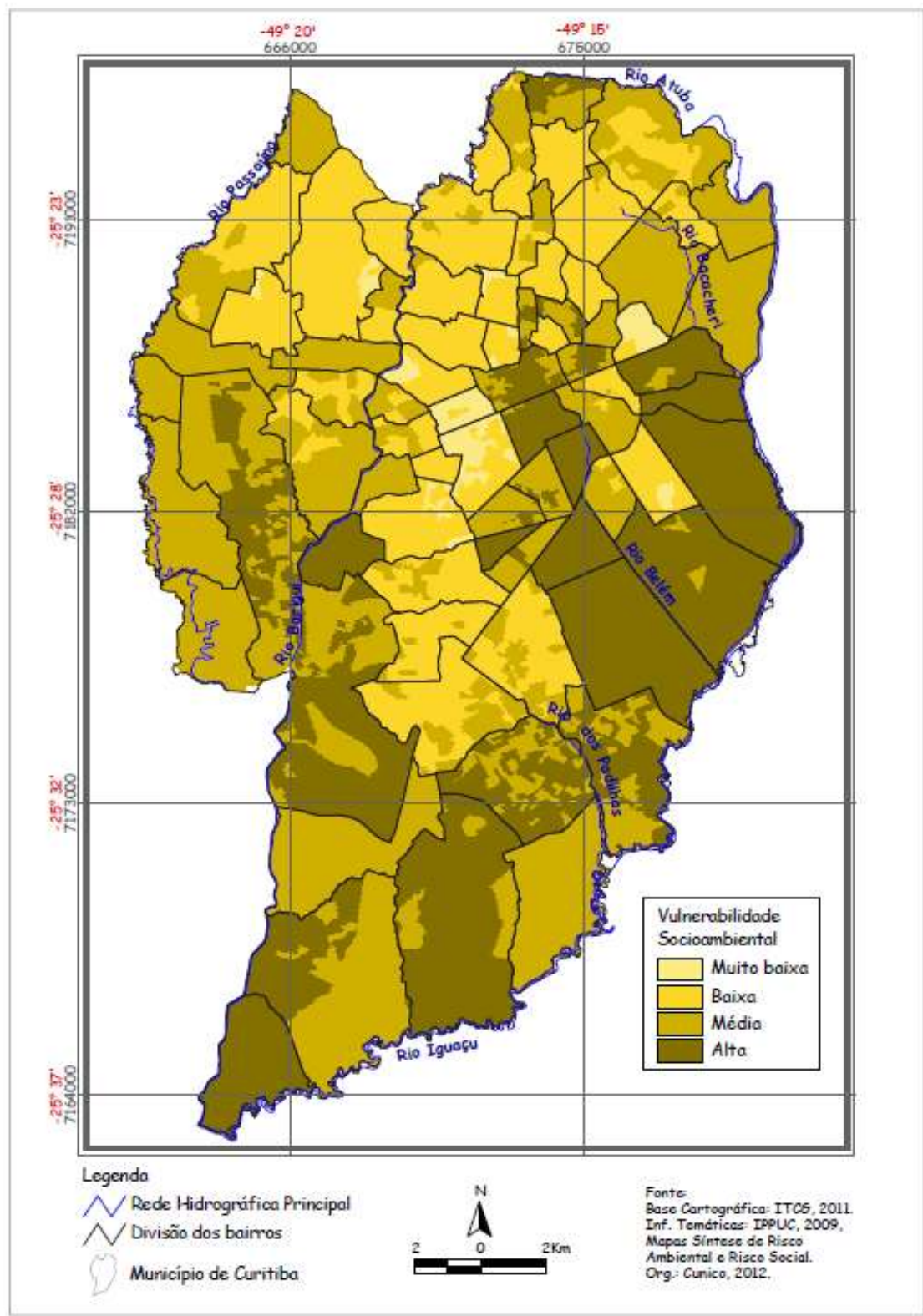

Figura 12 - Mapa de vulnerabilidade socioambiental do município de Curitiba 
cisco sáo contemplados pela classe de "muito baixa" vulnerabilidade socioambiental. Ressalte-se que tais bairros caracterizam-se por topografias menos acentuadas, menor quantidade de canais hídricos expostos na superfície e de planícies aluviais, densidade populacional média (401 - 100 habitantes) com maior poder aquisitivo. Para essa classe, o fator socioeconômico atenuou a vulnerabilidade estudada. $\mathrm{O}$ baixo risco ambiental não foi suficiente para evitar a ocorrência de eventos de alagamento, erosão e deslizamento.

Dos bairros mencionados destacaram-se pela ocorrência de eventos de alagamento: Santa Felicidade (49 registros), Jardim das Américas (42) e Portấo (29). Quanto aos eventos de erosão: Portão e Água Verde (19 registros cada) e Santa Felicidade (12). Por fim, os bairros Santa Felicidade e São Braz apresentaram um registro de deslizamento cada.

A classe de "baixa" vulnerabilidade socioambiental totaliza $111,70 \mathrm{~km}^{2}$ do município de Curitiba, o que representa $25,68 \%$ em relaçáo ao total da área de estudo. É constituída por manchas mais contínuas que contemplam os bairros do entorno daqueles que representam a classe de "muita baixa" vulnerabilidade socioambiental e os localizados principalmente na direção norte do município.

Os bairros representantes da classe de "baixa" vulnerabilidade socioambiental possuem como características comuns a clinografia variando de 3 a $20 \%$ e em alguns pontos específicos chegando a $30 \%$ de inclinação. É possível verificar também a existência de canais hídricos e de planícies aluviais. Quanto às variáveis socioeconômicas, saliente-se a tendência de aumento do crescimento populacional, que influencia diretamente a densidade demográfica; e a de aumento do poder aquisitivo da população, semelhante à média do município. Como exemplos exclusivos dessa classe, cite-se os bairros Ahú, Cabral, Mercês e Vila Izabel.

Quanto aos eventos pesquisados, saliente-se que nos bairros pertencentes à classe de "baixa" vulnerabilidade socioambiental, os alagamentos são frequentes, sendo os bairros mais assolados: Xaxim (88 registros), Pinheirinho (71), Santa Cândida (64) e Capão Raso (50).

A classe de "média" vulnerabilidade socioambiental caracteriza os bairros localizados no extremo norte, no oeste e no sul do município. Tais bairros são analisados sob dois aspectos físico-naturais: os localizados nas porçôes norte e oeste possuem condiçôes físico-naturais mais propensas aos eventos de deslizamento e erosão, enquanto que os localizados ao sul, mais propensos aos eventos de alagamento. São bairros mais periféricos, cujas condiçóes socioeconômicas caracterizam-se por elevado crescimento populacional, quando comparados os Censos Demográficos de 2000 e 2010, tendência de adensamento populacional e baixo rendimento mensal dos responsáveis pelos domicílios particulares permanentes.

Dessa forma, conclui-se que tanto as condiçóes físico-naturais, quanto as condiçóes socioeconômicas contribuem para que tais bairros sejam elencados na categoria de "média" vulnerabilidade socioambiental, dentre os quais podemos citar como exemplos: Atuba, Bairro Alto, Ganchinho, Orleans, Santa Quitéria, Tatuquara e Riviera. Nos bairros com "média" vulnerabilidade socioambiental, os eventos de alagamento são mais comuns, destacando-se: Cidade Industrial (272 registros) e Sítio Cercado (137).

A última classe identificada pela metodologia adotada é a de "alta" vulnerabilidade socioambiental que se localiza na porção leste, oeste e sul do município de Curitiba, sendo o bairro Cachoeira o único representante na porção norte, tendo sua condição de risco acentuada em função das condiçóes topográficas. Os demais bairros possuíam condiçóes físico-naturais propícias para a ocorrência de eventos de alagamento, em função da presença significativa de áreas de planície. Além de tais características, apresentaram condições socioeconômicas muito peculiares: grande crescimento populacional absoluto, elevado número de crianças, densidade demográfica atenuada em função da área extensa e renda dos responsáveis pelos domicílios particulares permanentes, em média, inferior a cinco salários mínimos. Destacaram-se, neste caso, os seguintes bairros: Alto Boqueirão, Boqueirão, Campo de Santana, Centro, Hauer e Umbará. Quanto aos eventos de alagamento destacaram-se: Cajuru (158 registros), Uberaba (155) e Boqueirão (119). No caso das erosôes destacam-se: Centro (31 registros), Cajuru e Uberaba (15 registros cada).

Saliente-se que o bairro Cidade Industrial também poder ser exemplo da classe de "alta vulnerabilidade", uma vez que, em função da extensão territorial, apresentou diversidade quanto aos componentes físico-naturais e socioeconômicos. Assim, apresentou vulnerabilidade socioambiental "média" e "alta".

\section{CONSIDERAÇÓES FINAIS}

Após a realização dos mapeamentos temáticos e das análises, pode-se concluir, comparativamente, que as áreas com alta vulnerabilidade socioambiental apresentam condiçóes socioeconômicas piores, do que aquelas áreas com menor grau de vulnerabilidade socioambien- 
tal, além de áreas com alta concentração populacional, em especial a presença acentuada de crianças e adolescentes; maior quantidade absoluta de responsáveis por unidades domiciliares analfabetos; infraestrutura urbana mais precária; maior concentraçáo de eventos de alagamento; e menor capacidade de resposta frente a situaçôes de emergência. Tal constataçâo revela a existência de áreas críticas na cidade, onde ocorre a concentração de problemas socioambientais e, consequentemente, dos riscos a eles inerentes.

As áreas críticas mencionadas estão diretamente vinculadas às práticas inadequadas no uso e cobertura da terra, à expansão do mercado imobiliário e à falta de poder aquisitivo de uma parcela significativa da população, fatos esses que induzem a ocupação das áreas de risco e das áreas degradadas ambientalmente por pessoas com baixa renda. Outra constatação plausível é a da ocupação irregular, principalmente nas margens dos rios.

Dessa forma, conclui-se que a diversidade de uso e cobertura da terra, bem como a sua intensidade, potencializa os riscos ambientais, além de aumentar a vulnerabilidade local. As diferenças no uso e cobertura da terra entre os grupos de "baixa" e "alta" vulnerabilidade socioambiental são expressivas, sendo que, nesse último grupo, é necessária a intervenção pública para planejar e reordenar o espaço urbano na tentativa de minimizar as diferenças e o número de habitantes afetados pelas ocorrências de evento críticos.

Por final, e preciso lembrar que a classificação em diferentes categorias e a identificação da vulnerabilidade, dos riscos e perigos por meio de mapeamentos fornece subsídios aos processos de planejamento, à implementação de políticas públicas integradas com base técnica, científica e operacional. Assim, tais mapeamentos não podem ser compreendidos como o resultado final de um processo, e, sim, como o insumo para medidas mitigadoras. Portanto, são passíveis de modificaçóes, tendo em vista que, dependendo das ações mitigadoras, poderá se desencadear processos que reduzem a vulnerabilidade $\mathrm{e}$ consequentemente os riscos e perigos. Alteraçóes no estrato físico-natural e até mesmo na produção social são condicionantes que poderão proporcionar novamente $\mathrm{o}$ aumento da vulnerabilidade.

\section{REFERÊNCIAS}

ALVES, H. P. F. Vulnerabilidade socioambiental na metrópole paulistana: uma análise sociodemográfica das situaçóes de sobreposição espacial de problemas e riscos sociais e ambientais. Revista Brasileira de Estudos da População. v. 23. n.1. São Paulo, 2006.
ALVES, H. P. F. Desigualdade ambiental no município de São Paulo: análise da exposição diferenciada de grupos sociais a situaçôes de risco ambiental através do uso de metodologias de geoprocessamento. Revista Brasileira de Estudos da Populaçâo. v. 24. n.2. São Paulo, 2007.

ALVES, H. P. F.; TORRES, H. G. Vulnerabilidade socioambiental na cidade de Sáo Paulo: uma análise de famílias e domićlíios em situação de pobreza e risco ambiental. São Paulo em Perspectiva. v. 20, n. 1. São Paulo: Fundação Seade, 2006.

ALWANG, J.; SIEGEL, P. B.; JORGENSEN, S. L. Vulnerability: a view from different disciplines. Washington, D.C.: World Bank, 2001.

BERTALLANFY, L. von. Teoria Geral dos Sistemas. Petropólis: Editora Vozes, 1973.

BOSCARDIN, C. R. A gestão de bacias hidrográficas urbanas: a experiência de Curitiba. 2008. Mestrado (Mestrado em Gestão Urbana) - Programa de Pós-Graduaçáo em Gestão Urbana, PUC, Curitiba - PR.

BOTELHO, R. G. M. Bacias Hidrográficas Urbanas. GUERRA, A. J. T. (org.). Geomorfologia Urbano. Rio de Janeiro: Bertrand Brasil, 2011.

CARTIER, R.; BARCELLOS, C.; HÜBNER, C. PORTO, M. F. Vulnerabilidade social e risco ambiental: uma abordagem metodológica para avaliaçâo de injustiça ambiental. Caderno de Saúde Pública. Rio de Janeiro: Escola Nacional de Saúde Pública Sérgio Arouca, Fundaçáo Oswaldo Cruz, 2009.

CUNICO, C; OKA-FIORI, C. O estado de normalidade e o estado de exceçáo diante da importância das categorias de "vulnerabilidade", "risco" e "resiliência". Caminhos de Geografia Uberlândia. v. 15, n. 52. Uberlândia, 2014.

CUNICO, C. Do risco à adaptação: a identificação da vulnerabilidade socioambiental de Curitiba - PR. 2013. Tese (Doutorado em Geografia) - Programa de Pós-Graduação em Geografia, UFPR, Curitiba - PR.

HOGAN, D. J.; MARANDOLA JR. E. Para uma conceituação interdisciplinar da vulnerabilidade. CUNHA, J. M. P. (org.). Novas metrópoles paulistas: população, vulnerabilidade e segregação. Campinas: NEPO/UNICAMP, 2006.

IBGE - Instituto Brasileiro de Geografia e Estatística. Base de informaçóes do Censo Demográfico 2010: resultados do universo por setor censitário. Rio de Janeiro: IBGE, 2011.

JACOBI, P. Impactos socioambientais urbanos - do risco à busca de sustentabilidade. MENDONÇA, F. (org.). Impactos Socioambientais Urbanos. Curitiba: Editora da Universidade Federal do Paraná, 2004. 
LOHMANN. M. Regressão logística e redes neurais aplicadas à previsão probabilística de alagamentos no município de Curitiba, PR. 2011. Tese (Doutorado em Geografia) Programa de Pós-Graduação em Geografia, UFPR, Curitiba - PR.

NUNES, L. H. Mudanças climáticas, extremos atmosféricos e padróes de risco e desastres hidrometeorológicos. HOGAN, D. J.; MARANDOLA JR., E. (orgs.). População e mudança climática: dimensóes humanas das mudanças ambientais globais. Campinas: NEPO/UNICAMP, 2009.

SÁNCHES, L. E. Avaliação de impacto ambiental: conceitos e métodos. São Paulo: Oficina de Textos, 2008.

SANTOS, R. F. Planejamento Ambiental - teoria e prática. São Paulo: Oficina do Texto, 2004.

SOTCHAVA, V. B. Por uma teoria de classificação de geossistemas de vida terrestre. Biogeografia, n. 14. Sáo Paulo, 1978.

YAMAMOTO, C. R. G. Wetlands na Regiāo Metropolitana de Curitiba - PR: diagnóstico, conflitos socioeconômicos e desafios de gestão. 2011. Tese (Doutorado em Geografia) - Programa de Pós-Graduação em Geografia, UFPR, Curitiba - PR.

\section{Correspondência do autor:}

\section{Camila Cunico}

camilacunico@yahoo.com.br.

Marciel Lohmann

marciel_lohmann@yahoo.com.br. 